\title{
Glacier Geosite of Tale-Tange Valley
}

\section{KAMRAN REZAEIZADEH MAHABADI ${ }^{1}$ and ASEMEH SOLEIMANIFAKHR ${ }^{2 \star}$}

\author{
${ }^{1}$ Department of Geography, Faculty of Science, Shahr-e-Rey Branch, \\ Islamic Azad University, Tehran, Iran. \\ ${ }^{2}$ Department of Geography, Faculty of Literature, Central Tehran Branch, \\ Islamic Azad University, Tehran, Iran.
}

http://dx.doi.org/10.12944/CWE.9.2.30

(Received: June 03, 2014; Accepted: July 15, 2014)

\begin{abstract}
Geological sites or geosites are the key evidence or specific periods of geological history which are very important in public education of earth sciences and environmental implications. They are also non-renewable parts of the earth as a tool for sustainable development. By its diverse geology, climate, geological features and unique nature, Iran can use geological phenomenon (geotope) across the country, such as caves, canyons, valleys, fossil sites, geological formations, mud volcanoes, types of minerals, mountain glaciers, and Kaluts As a geological heritage in the form of multiple potential geosites following the provision of tourism infrastructure, as a useful tool for geotourism development and establishment of geoparks. Tale-Tange valley is located in northern Jajrud Basin in the southern highlands of central Alborz. Several geomorphological phenomena such Cirque glaciers, moraines, waterfalls, River terraces, wandering rocks in the area can be a geotourist factor to attract tourists to this region. Hence, the area can be considered as a paleoclimatic site or geosite.
\end{abstract}

Key words: Geosite, Geotourism, Glacier Cirque.

\section{INTRODUCTION}

Geotourism is a branch of tourism as a new term recently used in tourism campaign of countries. Wherever one goes is on the earth, every part of the earth has its geological unique attractions, referring to the tourism based on geologic resources. Geotourism formation in the second half of the twentieth century is a new type of human activities associated with nature and its exploitation. The practical aspects of Geosciences in relation to tourism have resulted in formation of terms such as inheritance, geotope, geotourism, geopark, and geosite (Zandi, 2010).

Tourism is the main factor for sustainable development in the economic, social, cultural and environmental levels. Geotourism is the subset of sustainable tourism and its purpose is to conserve tourism land resources and develop tourism destinations, namely, to guide tourists so that the visited geosite can be used and maintained for future generations (Kazazi, 2006).

In one category, Geotourism can be divided into two categories:

\section{Geopark}

Geopark is a National protected area with at least one heritage site of geosciences which is important in scientific, rarity and aesthetics terms (Zandi, 2010).

\section{Geosite}

Geosite refers to a place with a rare and valuable geological or geomorphological phenomenon. These sites should be scientifically and aesthetically valuable and the possibility of visiting should be available publicly. Geosites are unique areas which can be visited by Geotourists. 
In addition, a series of geosites can be found within a geopark (ibid).

Tale-Tange Valley with its natural attractions such as river, waterfall, fountain, beautiful mountain scenery along its geomorphological phenomena such as glacial cirques, river terraces, wandering rocks and moraines can be a good platform for research and development of Geotourism and tourism in the region.

\section{Problem Statement}

By glacial and climatic evidence and heritage, Tale-Tange Valley provides valuable information on the life and climate and its changes during different geological periods. However, as a geosite, its geotourism potentials can attract domestic and foreign tourists with various objectives.

Development of activities coordinated and consistent with the area, in addition to maintaining environmental integrity, can provide economic development and improve the livelihood of local people.

\section{Objective}

The purpose of this study was to present TaleTange Valley as one of the sites of geomorphological and paleoclimatic studies in line with development of tourism industry and Geotourism.

\section{Hypotheses}

It seems that the research area has a great potential for tourism and paleoclimatic studies.

\section{Literature Review}

Geotourism is a new term in tourism, introduced for the first time in Iran by Nabavi (1999). Afterwards, major works conducted on Iranian geotourism include studies of Kazemi (2002, 2004, and 2006).

Kamyabi (2008) evaluated the natural and Geotourism attractions of Hablehrud basin and National Park of Semnan Desert. He suggested that the area had the ability to become a geopark through development planning and optimal utilization of geotourist systems.

Using the term, geomorphotourism and geotourism, Zomorrodian (2005) and Servati (2006) studied the north coast of the Caspian Sea and Hamadan, respectively.

Articles are also written in this field. T h e Nojavan and colleagues (2009) considered geotopes of Yazd as potential for development of tourism and geotourism. Taheri and Moradnejad (2010) introduced the glacial alpine environments of Ashtarankooh as a geosite.Studying fossil geosite of Maragheh, Safari Paskeh (2001) studied variety of fossils and places where they were discovered as a fossil site. In the first conference of Geological Heritage of Iran, Shah Amiri Tabatabai and Ghassemi (2012) introduced Tang-Tikab geosite and Devon village, Kazeron, as one of the tourist attractions in the Fars province. Maleki Orsi and colleagues (2012) introduced the Aras Geo Park and Uch Tepe geosite.

\section{Methodology}

Methodology of this survey involves:

\section{Methods of Data Collection}

A) Referring to libraries of universities, institutions and organizations

B) Using 1:50,000-, 1:100000- and 1:250000scale topographic and geological maps provided from geographical organizations of the Armed Forces, Organization of Geology and Mapping Agency (type and age of the rocks were examined by geological map).

C) Field methods; to record information from field observations,

Following methods were used:

a. Phenomena recorded on maps or aerial or satellite photographs: 1:55000-scale aerial photographs were prepared and interpreted from geographical organization of the Armed Forces. The satellite images were interpreted using Google earth software. Complications such as faults, valleys, water bodies were detected from these images.

b. Explanatory Notes

c. conventional photographs and required samples of the land

\section{Analysis of Data}

In this section, the information collected were analysed in this form of sketch or photo. The Best way to adjust the structure of this section 


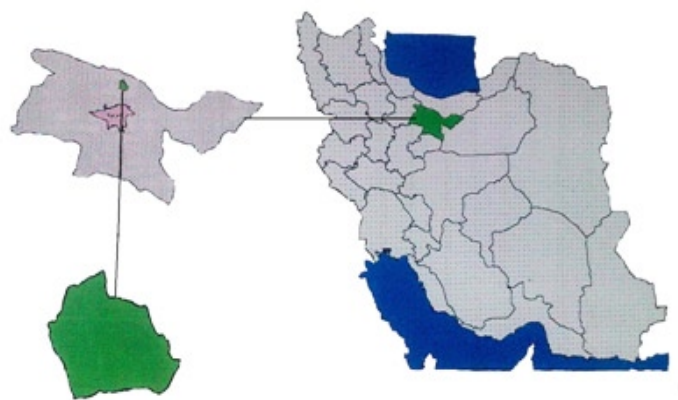

Fig. 1: Geographical location of Tale-Tange Valley

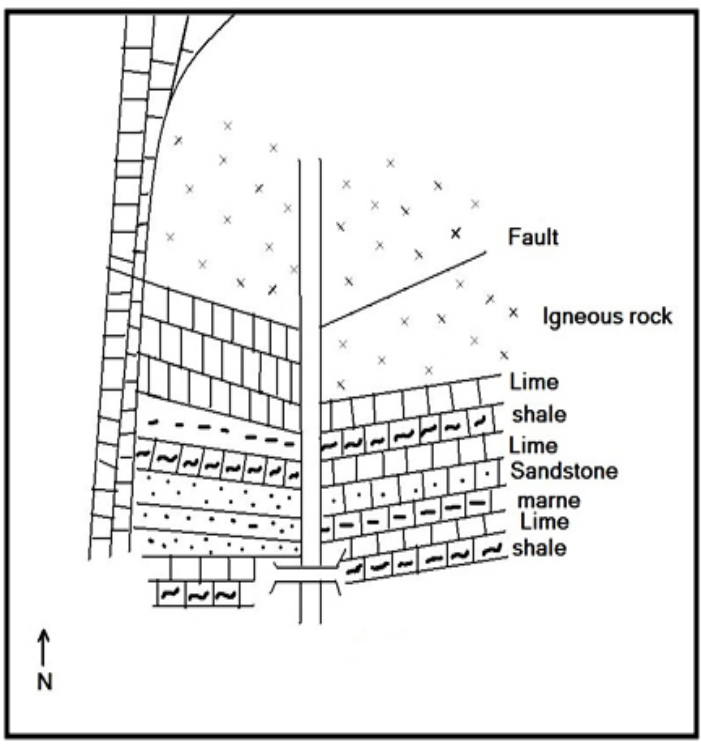

Fig. 2: lithology sketch of Tale-Tange Valley

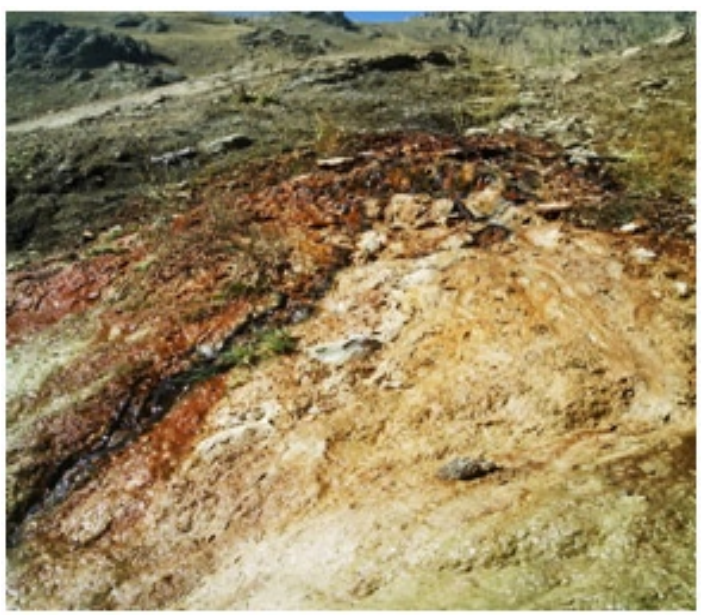

Fig. 3: sour-water spring; photo by author, 2008 is to present findings regarding questions and hypotheses.

\section{DISCUSSION}

Tale-Tange Valley is located in southern Alborz Mountains, in the northeast Darbandsar. This valley, as one of the highest branches of the main Jajrud River, is located at 51Ú28' east longitude and 36 Ú15 North latitude (figure 1)

\section{Geology of the Area}

At the entrance of the valley, there are Shemshak formations including charcoal shales, limestone, calcareous sandstones with large amounts of coal between the layers (Figure 1). By $200 \mathrm{~m}$ to the eastern slope, there is a glacier cirque at an altitude of about 3000 meters. There is a valley at the north of the cirque characterized by a sour-water spring with red sediment (Figure 2).

This valley ends to larger cirques at an altitude of about 3400 meters. From this valley to north, there is a lithologic shift from sediment to Igneous (Figure 3). To the end of the valley, igneous rocks form the completely eastern wall $(800 \mathrm{~m})$ continuing to the heights of the sour-water river.

According to the geological map, the rocks are related to the Upper Cretaceous mostly seen as green and grey-green. These rocks are strongly influenced by tectonics in different geological periods; so that, some parts of the large and small pieces became mylonitic. Depending on lithology, weather and steep rock as well as slopes, particularly after the sour-water river, there are highly active Debris slopes.

This is different in the western foothills. First, the place where grain turn from sedimentary rock to igneous rocks is not too noticeable; there is a freshwater spring which totally wet the environment. In addition, it is Slippery because of Vegetation such as algae. Secondly, there are calcareous sediments on igneous rocks, which caused a relatively good vegetation. This prevents debris; instead, calcareous sediments fall from upside because of Erosion and breakage. 
After about 700 meters from the entrance of the valley, there are igneous rocks which are foundation stone of ... limestone. In two places at the contact of limes and igneous rocks, there is a spring.

The first spring which has a wall with a nearly Perpendicular slope and less water creates an ice waterfall from November to May; in other warm months, there is only humidity of the waterfall (Figure 5). The next spring at the contact of calcareous rocks and igneous rocks has water at all during the year, some of which are transmitted by a channel to Darbandsar.In General, geological structure of the valley starts from entrance by Shemshak formations and ends to limestone and igneous rocks of the Upper Cretaceous at heights.

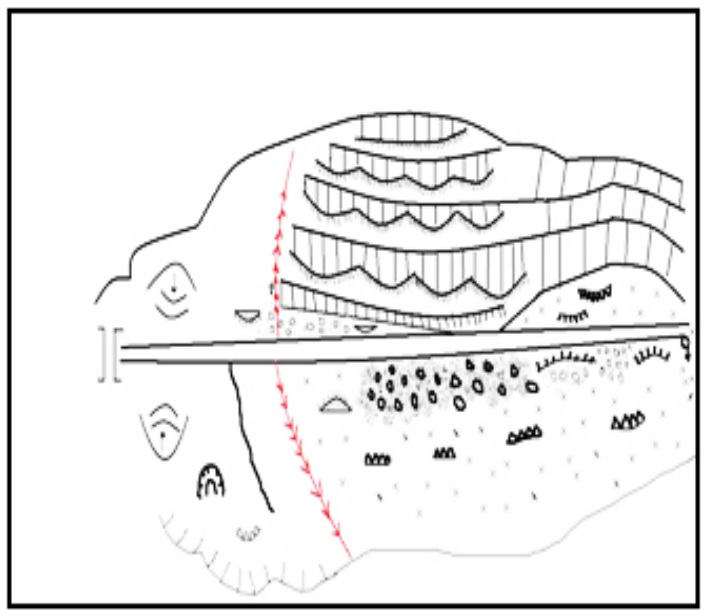

Fig. 4: geomorphology of the Tale-Tange Valley

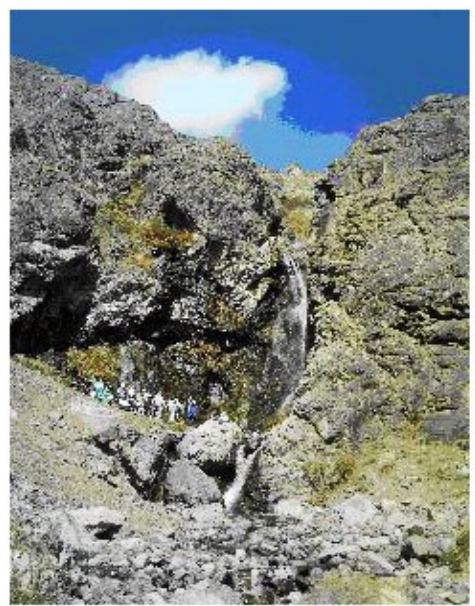

Fig. 5: waterfall of Tale-Tange; photo by author, 2008
To explain, igneous Shemshak formations rose from water in The Triassic Period. Through Next orogenic processes, it is likely that Laramide of igneous materials have fall on them; or given the tuffs and andesite tuff, it is likely that the sea was not too deep to cover the area permanently; therefore, andesites flew on tuffs.

After some times, volcanoes extinct and the sea progressed; the limestones deposited on them and then they rose of the water during the early Tertiary orogenic or the same period. Along with dolomite, there was limestone.

High altitude and mountainous cool weather prevent fast snow melting; occasionally, snow can be seen in the region until early June. During the cold
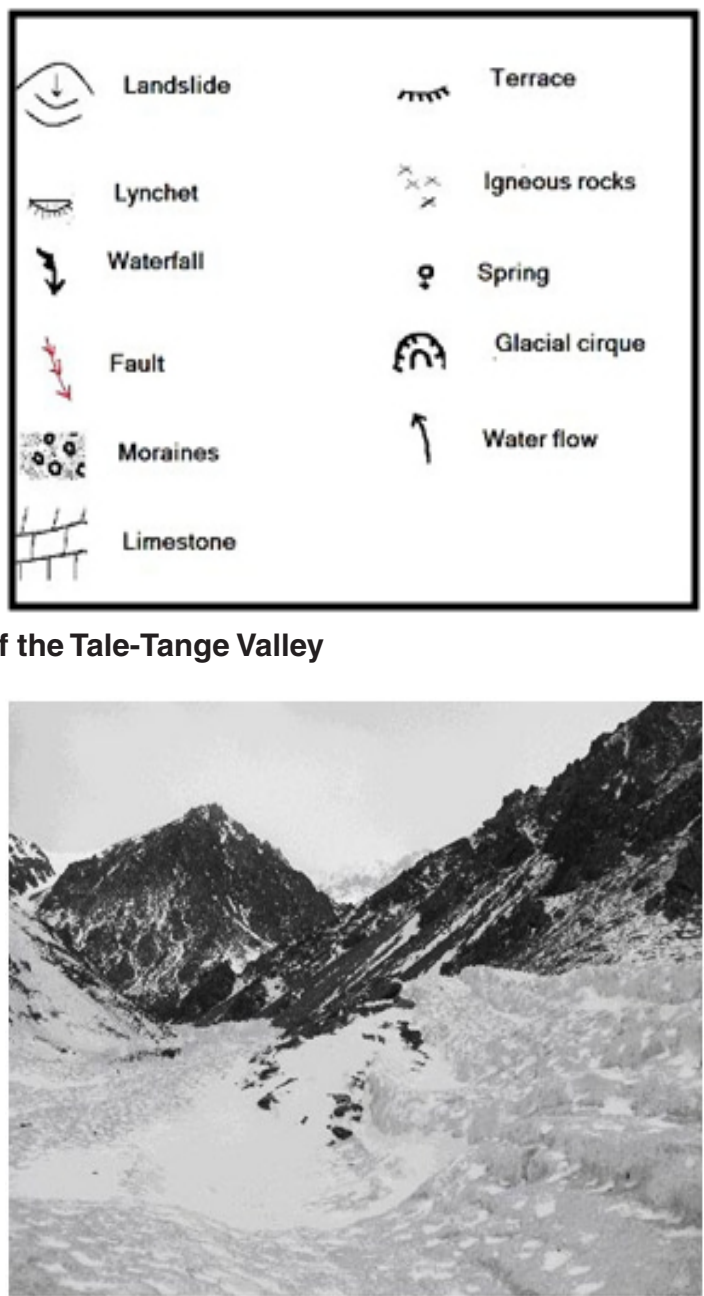

Fig. 6: Avalanche in Tale-Tange Valley; photo by author, 2008 


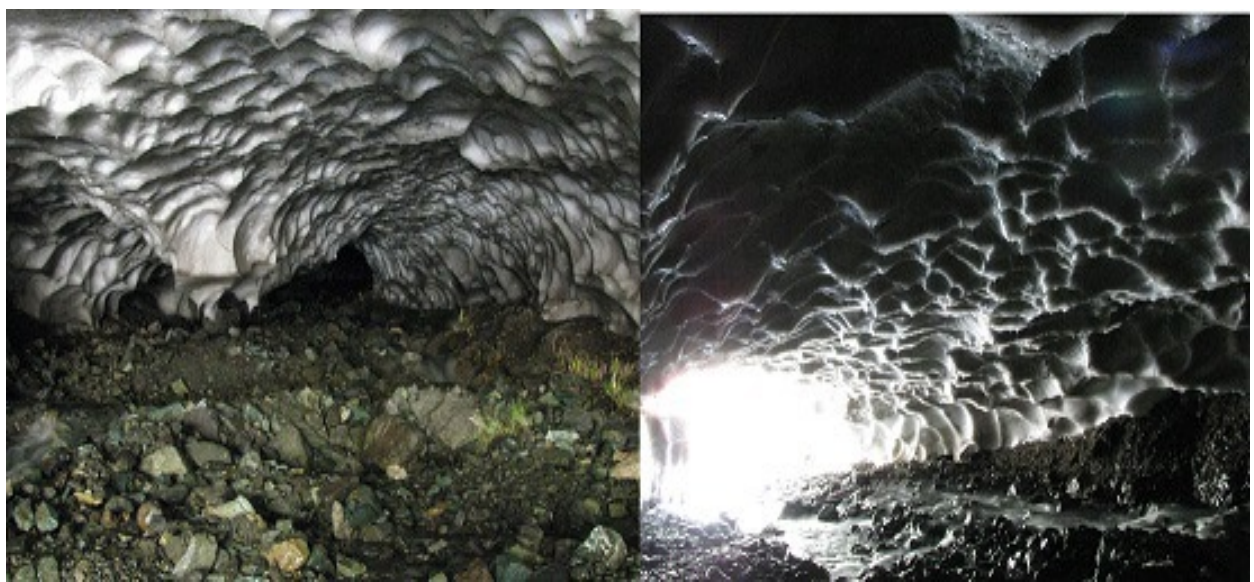

Fig. 7: Snow tunnel; photo by author, 2008

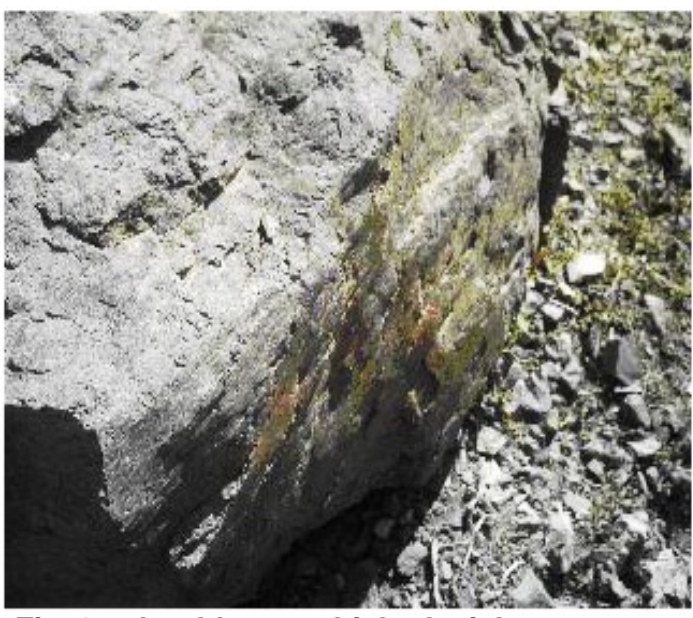

Fig. 8: a boulder on which glacial movements is obvious; photo by author, 2008

period which starts from October, there are solid falls which are not melted because of cold weather. Due to slopes, the snow covering slopes spills into the glacier valley as numerous avalanches (Fig. 6) and covers the entire valley. For example, the snow depth was about $30 \mathrm{~m}$ at sour water valley in 2006 . This snow remains to the end of the water year. Through tunnels under the ice, stream continues and creates beautiful caves (Fig 7).

Blocked paths due to the avalanche probability in SHEMSHAK-Dizin axis in most cold months prevents further investigation. Given the evidence remaining from this condition, some results can be drawn in relation to cold periods. The fractured angled rocks indicate physical erosion caused by glaciation. Varnished stones which glow

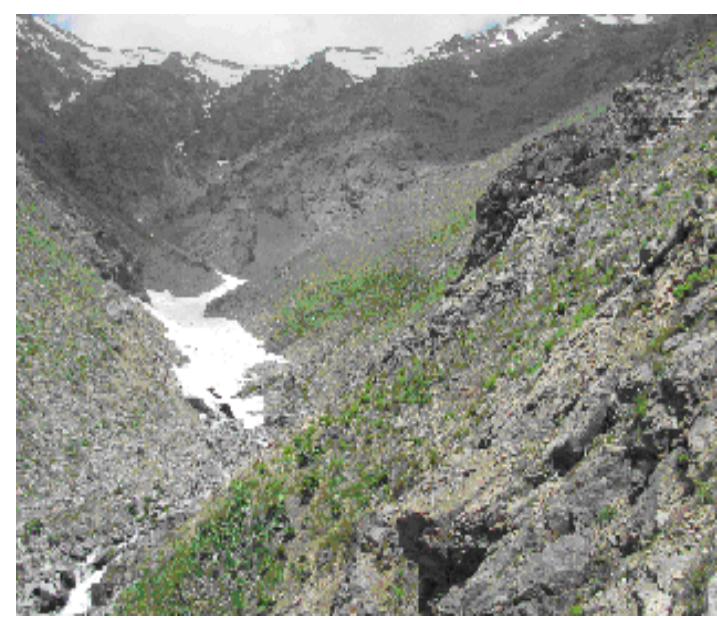

Fig. 9: glacier cirques of the valley; photo by author, 2008

in the sunlight indicate their erosion by ice tabs (Fig 8).

This is true for small and large glacial cirques including the end of the valley which is dead. This relatively large area represents inside of a circus which is terminated to the main valley by a narrow gorge (Figure 9). Morins of these cirques are seen with large boulders in the river valley as a sign of glacial activity. There are three terraces on the western slopes of the Valley indicating reduced temperature. Genesis and evolution of terraces could be related to heavy rains associated with the later glacial stages, effective on sediment erosions or due to continuous orogenic movements, or the performance of both. 
It is noteworthy that, straw fossils found in the beginning of the valley indicate a warm weather prior to Tertiary and a shallow sea. Thus, this region, like other parts of Iran, has been experiencing temperature fluctuations.

\section{CONCLUSION}

Accordingly, Tale-Tange Valley with glacial features along pristine mountain nature can attract domestic and foreign tourists every year. Existence of the natural phenomena provides the potential for attracting tourists and enriching their leisure time as well as a useful platform for scientific studies. It is hoped tourism resort projects and development of tourism infrastructure in the area attract tourists and Geotourists.
Given the location of Iran in desert strip and problems related to water crisis, the valley can be considered as a resource to provide fresh water in future due to the fact that the valley is under ice at most time of the year.

By glacial and geomorphological phenomenon, the valley can be viewed as a potential geosite interested by tourists and geotourists.

\section{ACKNOWLEDGEMENT}

This article is from the statements and guidance of the late doctor Mohammad Asghari Moghaddam; God bless his soul.

\section{REFERENCES}

1. Kazazi, E., Geotourism, a New Approach to tourism Planning; Zanjan Province (2006).

2. Maleki Orsi, S. \& Najaf Zadeh, Uch Tape Geosite in the Suggested Aras Geopark. s.I., s.n (2012).

3. Nojavan, M. R., Amir Hoseyni, A. \& Ramesht, M. H., Geotopes of Yazd and Its Attractions. Geography and Development (2009).

4. Safari Paske, H., n.d. Fossil Geosite of Maraghe.
5. Shah Amiri Tabatabai, R. \& Ghasemi, N., Tange-Tikab Geosite in Davan Village (Kazerun). s.I., s.n (2012).

6. Taheri, K., Taheri, M. \& Moradnejad, A., An Introduction to Glacial Geomorphology of Chal Kabud, Oshtoran Kooh; a Glacial Geosite in West Iran. s.I., s.n (2010).

7. Zandi, E., an Introduction to Geoturism and Potentials of Iran (2010). 